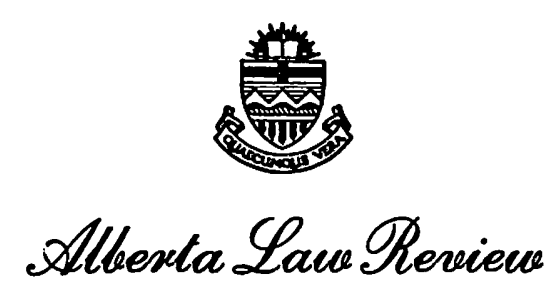

$$
\begin{aligned}
& \text { Faculty of Llaces } \\
& \text { The Ulsivensity of Allherita } \\
& \text { Édmonton, Allboxta } \\
& \mathscr{T}_{6} \mathscr{C}_{1}
\end{aligned}
$$

THE AUTHOR OF THE ARTICLE ON PAGE 302, VOLUME 14 OF THE ALBERTA LAW REVIEW SHOULD BE MR. BRIIN BURROWS, B. ., LL. B. MR. RAJIV MALHOTRA WAS INVOLVED IN AI: UPDATE OF THE ARTICLE. 


\title{
A STUDY OF THE ROLE OF ARBITRATORS IN COMMERCIAL ARBITRATION PROCEEDINGS*
}

\author{
RAJIV MALHOTRA**
}

The author examines the nature of the arbitration process and the role of the arbitrator in each of the major forms that the process takes. He concludes that an arbitrator appointed by mutual agreement of the parties must act judicially. Party appointed arbitrators also function in a judicial role, although an American trend away from impartiality is noted. In an arbitrator-umpire situation the party nominated arbitrators may act as advocates once they have referred the matter to the umpire.

\section{INTRODUCTION}

This paper will examine the nature of the role of the arbitrator in commercial arbitration proceedings. The present statutory law in Alberta is that embodied in The Arbitration Act. ${ }^{1}$ The discussion will center around the problem of whether the duty of an arbitrator is to remain neutral and impartial or to act as an advocate for the cause of the party who has nominated him. Dealing separately with each of the major forms that commercial arbitration proceedings can take, the present position in Canada will be outlined with reference to the respective positions of England and United States.

\section{A. Definition}

\section{THE NATURE OF ARBITRATION}

Halsbury's Laws of England2 defines "arbitration" as the "reference of a dispute or difference between not less than two parties for determination after hearing both sides in a judicial manner, by a person or persons other than a court of competent jurisdiction." Arbitration proceedings can be classified as either statutory or contractual. The Alberta Labour Act is an example of the former. ${ }^{3}$ Contractual arbitration encompasses arbitrations which the parties have agreed to undertake by their own initiative and are governed by The Arbitration Act. In such arbitrations, the dispute is referred to a private tribunal for hearing in a judicial manner in accordance with a fixed and recognized system of law. Since it is the parties themselves who set up the arbitration tribunal they intend to use, the variety of forms it can take is quite broad.

\section{$B$. Characterization}

The basic motivation behind the inclusion of an arbitration clause in a contract is a desire to employ a degree of expertise, efficiency, economy and informality in dispute settlement greater than that commonly available in court proceedings. Arbitration tribunals are frequently described as "courts" that the parties have set up for their own purposes. References to arbitration proceedings as "trials out of court"4 and to

- The text of this article is taken from a study done by the writer for the Alberta Institute of Law Research and Reform. The writer acknowledges with thanks the work of Brian Burrows, who did some of the original research, and Robert $L$. Phillips, who did the re-write and update for the study.

** LL.B. (New Delhi), LL.M. (Alta.). Legal Research Officer, Institute of Law Research and Reform.

1 R.S.A. 1970, c. 21. This Act is basically modelled after The English Arbitration Act of 1889.

2 (4th ed.) Vol. 2 at 255.

S.A. 1973, c. 33, 8. 138(1). Labour arbitrations may be said to arise out of a contract of labour but, by virtue of section 148, the Arbitration Act does not apply to them.

- Campbell v. Irwin (1914) 32 O.L.R. 48 at 54. 
arbitrators as "judges"5 are common. The basis for this judicial characterization of arbitration proceedings is the similarity between arbitration and litigation. Although there is some difference in procedure, the functions of both are to hear evidence and arguments submitted by both parties to the dispute and to determine what is a fair and just settlement.

An arbitration is a judicial or quasi-judicial proceeding, a trial out of court, a substitute for the ordinary method of trial, and, in such trials by laymen, although the judicial rules of procedure may be relaxed, they must not be ignored; there must be substantial compliance with the fundamental principles of investigation adopted by the courts. It appears, however, that arbitrators have traditionally been allowed considerably more leeway as to procedure and the conduct of their proceedings than has been the case in the ordinary civil suit litigation. In Glen v. GTR, for example, where arbitrators awarded damages in excess of the amount claimed, the court held that there was no ground for setting aside the award, since arbitrators are not bound as judges are in a court of law. This does not mean, however, that an arbitrator is entitled to disregard ordinary and clearly enunciated judicial principles, nor does it permit him non-judicial or biased conduct. ${ }^{7}$

Halsbury's Laws of England ${ }^{8}$ strengthens this indication of a close functional similarity between arbitrations and courts by stating that "the dispute or difference which the parties to an arbitration agreement agree to refer must consist of a judiciable issue triable civilly."

The English and Canadian courts have long characterized arbitration proceedings as "judicial" in distinguishing them from proceedings of other natures. In the early case of In Re Carns-Wilson and Green, Lord Esher, in distinguishing between arbitration and valuation proceedings, stated: ${ }^{9}$

If it appears from the terms of the agreement by which a matter is submitted to a person's decision, that the intention of the parties was that he should hold an inquiry in the nature of a judicial inquiry, and hear the respective cases of the parties, and decide upon the evidence laid before him, then the case is one of arbitration [and not valuation]. The intention in such cases is that there shall be a judicial inquiry worked out in a judicial manner. ${ }^{10}$ [emphasis added]

Again, the distinction between an arbitrator and a "quasi-arbitrator" (a person appointed to decide a dispute involving only the quality of the subject matter of the contract) is based upon the judicial nature of arbitration proceedings. ${ }^{11}$

It is clear therefore that the English and Canadian courts have looked upon arbitration proceedings as being of judicial character. It will be seen that such characterization relates to the question of the requisite neutrality and impartiality of the arbitrator in the various forms of arbitration.

s Maule v. Maule (1816) 3 E.R. 1194 at 1211.

' [1859] 2 P.R. 377.

i Re Walker and North Grimsby [1958] O.W.N. 269 (Ont. C.A.).

N Supra, n. 2 at 256.

${ }^{9}$ [1888] Q.B.D. 7 at 9.

10 See also Campbellford Etc. Ry. v. Massie [1914] S.C.R. 409, Re Windebank and C.P.R. (1915) 9 W.W.R. 715; Ritchie v. Snowball (1882) 26 N.B.R. 258 (rev'd. on other grounds 14 S.C.R. 741); Geary v. Clifton Co. [1928] 3 D.L.R. 64; Calgary v. Blow [1925] 3 W.W.R. 225. These cases further establish that arbitration is essentially a judicial proceeding and, therefore, in deciding a given reference, facts which point to the proceedings having a judicial character should be looked at.

"Finnegan v. Allen [1943] 1 All E.R. 493. 
There is, however, a contrary trend appearing in the United States. The former Dean of Yale Law School, Wesley A. Sturges, suggests that the judicial characterization of arbitration proceedings may be illfounded. He states: ${ }^{12}$

Sometimes arbitration is cited as being a "quasi-judicial tribunal" and arbitrators as being "judges" of the parties' choosing, "judicial officers" or officers exercising "judicial functions." Here again, the presentation of arbitration or arbitrators in the role of courts or judiciary is necessarily based upon remote resemblances. "Quasijudicial tribunal" and the other foregoing terms are not very meaningful.

Opinions designating the courts or the judiciary as "quasi-arbitral tribunals" or the judiciary or jury as "arbitrators", or the like, have not been observed. It is true that as judges and juries hear and decide litigated matters, so do arbitrators hear and decide matters submitted to them by parties. But here the resemblance ends. Arbitrators, as distinguished from judges, are not appointed by the sovereign, are not paid by it, nor are they sworn to any allegiance. Arbitrators exercise no constitutional jurisdiction or like role in the judicial systems-state or national. They are generally not bound to follow the law unless the parties so prescribe and, as unlikely as not, they are laymen technically unqualified (and not disposed) to exercise the office of the professional judge.

As pointed out above, the Supreme Court of Alabama excluded arbitration from an "act to regulate judicial proceedings." [Crooks v. Chambers (1866) 40 Ala. 239]. . . .

In 1931, the New York Appellate Division summarized the dissociation of arbitrations, awards and arbitrators from judicial proceedings, judgments and the judiciary in refusing to grant an order of prohibition against common law arbitration. . . . The Court observed:

This was an attempted common-law arbitration which is a contractual, not a judicial proceeding, and, if properly conducted, results not in a judgment, but in a cause of action against the party who does not obey the award. The arbitrators do not constitute a judicial or quasi-judicial body whose proceedings are the subject of an order of prohibition. [Fidelity and Deposit Co. v. Wolz 235, N.Y. Supp. 583 (4th De't. 1931) (Per Curiam.)]

The process of making judges of arbitrators and judicial proceedings of arbitrations seem to be at its best, when used arguendo to reaffirm the parties' right of hearing in arbitrations, to raise the finality and conclusiveness of awards to those of "a judgment" or to lend stature to some set of facts being made up in a given case as cause for disqualification of the arbitrator, as for insufficient "honesty" or "impartiality", undue "bias" or "misconduct".

As further litigation centers upon arbitrations and awards, so may the usages of analogy, metaphor and the making of classifications in the course of the judicial process confound and complicate the role of the arbitral process as presently conceived in legal tradition.

In addition to this suggestion that arbitration should not be characterized as judicial, Dean Sturges submits earlier in his article that there are significant requirements governing arbitrations. ${ }^{13}$ These minimum legal requirements ensure both parties of their mutual rights of hearing. Mutual rights that, after hearing, the arbitrators shall render their award on the issues submitted to them as they deem fair and justwhether or not according to law. This suggestion that arbitrators are not bound to follow the law appears in the quoted postion of his article as well.

It is submitted that Sturges' statements do not accurately represent the law in Canada or England. Russell provides: ${ }^{14}$

It is the duty of an arbitrator, in the absence of express provision in the submission to the contrary, to decide questions submitted to him according to the legal rights of the

32 Sturges, Arbitration, What ls It?, 35 New York University Law Review 1031 at 1045.

13 Id. at 1031 .

14 Russell, Russell on Arbitration, 18th ed., edited by Anthony Walton, Stevens, London 1970 at 186. 
parties, and not according to what he may consider fair and reasonable under the circumstances . . . [emphasis added]

and he cites "Vulcaan" v. Mowanckels Rederi"15 and Jager v. Tolme. ${ }^{16}$ In addition, it has been decided in both Canada and England that one ground for setting aside an award is that the record shows that the arbitration proceeded upon an erroneous view of the law. ${ }^{17}$

It becomes difficult to determine what lies between that which Sturges puts forward as being descriptive of arbitration and the judicial characterization. "Judicial" is not a term that enjoys a precise definition, but it is submitted that the mere addition of the words ". . . in a manner approximating that employed by the courts" to each of the two characteristics submitted in the article as minimum legal requirements would yield a definition of the term acceptable to a Canadian court. ${ }^{18}$ One is left with the conclusion that Sturges' objection to the use of the term "judicial" to characterize arbitration proceedings must be based on a definition of that term which varies significantly from that acceptable by Canadian Courts. At any rate, in that the characterization that Sturges would accept is sufficiently close to what other authorities would consider as incorporated in the term "judicial", the apparent inconsistency need not be considered further. An exact determination of what Sturges would accept as a definition of the term "judicial" is beyond the purpose for which this discussion was entered.

The judicial characterization of arbitration has many consequences. In general, however, they may be summed up in the statement that the arbitrator is bound to adhere to the rules of natural justice. In particular it should be observed that a duty of impartiality is placed upon the arbitrator as evidenced in cases where the arbitrator was disqualified by reason of the fact that he and one of the parties to the contract were of such a relationship that a lack of impartiality could be presumed. Thus the fact that the arbitrator had acted as solicitor for one of the parties warrented the court to set aside the award. ${ }^{19}$ In another case, the arbitrator was an engineer employed by one of the parties to the dispute so that his award was set aside. ${ }^{20}$

If no reasonable apprehension of partiality arises out of a relationship between the arbitrator and one of the parties, the award may still be set aside on the ground that the arbitrator's conduct or expressions clearly give rise to an inference of bias. ${ }^{21}$

Furthermore, an award can also be upset where the arbitrator receives evidence from one party in the absence of the other and such evidence is not communicated to the other party. ${ }^{22}$ This is so even where

is [1938] 2 All E.R. 152.

Is [1916] 1 K.B. 939.

17 Martineau v. Montreal (1932] 1 W.W.R. 302; Lacoste v. Cedar Rapids [1928] 2 D.L.R. 1; Fraser v. Fraserville [1917] 2 A.C. 187.

I" Judicial definitions of the word "judicial" can be found in Royal Aquarium v. Parkinson [1892] 1 Q.B. 431 at 452: The word "judicial" has two meanings. It may refer to the discharge of duties exercisable by a judge or by justices in Court, or to administrative duties which need not be performed in Court, but in respect of which is necessary to bring to bear a judicial mind-that is, a mind to determine what is fair and just in respect of the matters under consideration.

Also in R. v. St. Lawrence's Hospital [1953] 2 All E.R. 766 at 768 :

A body bound to 'act judicially' is one which is bound to hear evidence from both sides and to come to a judicial decision approximately in the way a court must do.

19 Summer v. Barnhill (1979) 12 N.S.R. 501 (C.A.).

to Brennan and Hollingworth v. Hamilton (1917) 39 O.L.R. 367.

${ }^{2}$ Re Ryan, Chapman \& Co. v. Pomroy (1852) 1 P.R. 59; Szilard v. Szasz [1953) O.W.N. 907, rev'd. on other grounds [ 1955] S.C.R. 3.

"2 Cruikshank v. Corby (1880) 30 U.C.C.P. 466, aff'd. 5 O.A.R. 415. 
the arbitrator swears that the evidence so received did not influence his decision, ${ }^{23}$ and the court believes him. "The award may have done perfect justice, but upon general principle it cannot be supported."24

It is therefore apparent that the judicial character of the arbitration process and the resultant requirement that the arbitrator conduct himslef impartially is given strict application.

\section{THE TYPES OF ARBITRATORS}

Arbitration tribunals can take one of at least three forms:

(A) Sole Arbitrator: The parties agree to refer disputes to a single arbitrator, the appointment of whom is by their mutual agreement.

(B) Tripartite Board: The parties agree to refer disputes to a board of three members, one member being appointed by mutual agreement of the parties, or of the first two nominated members. Each member of the board, regardless of the method by which he was appointed has equal status in the decision-making process.

(C) Arbitrator-Umpire: The parties agree to refer disputes to a board of two members, each party to the dispute appointing one. Should this board fail to agree to an award, the dispute is referred to an Umpire chosen mutually by the original arbitrators. The Umpire is in the same position as a sole arbitrator at that point. ${ }^{25}$

\section{A. The Sole Arbitrator}

It is, of course, clear that a sole arbitrator, mutually appointed by the parties, who behaves as an advocate of one of the parties would be misconducting himself in a manner which would render his award liable to vacateur. ${ }^{26}$

\section{B. Party-Nominated Arbitrators}

Although it is clear that a sole arbitrator must remain neutral and impartial, it must be determined whether or not the position differs where the arbitrator is not chosen by mutual agreement but rather is nominated by one of the parties. Party-nominated arbitrators are employed in the latter two forms of tribunal described above. It will be convenient to consider the role of the party-nominated arbitrator in three situations:

1. in tripartite arbitration,

23 Waters v. Daly [1860] 2 P.R. 202.

24 Walker v. Frobisher (1801) 6 Ves. 70 (per Lord Eldon at 72).

25 It is important to note that taiks have revealed that the arbitrator-umpire form of tribunal is rarely, if ever, used in Alberta.

26 It may be difficult to imagine circumstances where a sole arbitrator or an empire could conduct himself as an advocate of one of the parties since advocacy implies at least two people-one to speak and one to listen, but in London Export Corporation v. Jubilee Coffee Roasting Company Led. [1958] 1 W.L.R. 271 it may be possible to say that such circumstances existed.

There the matter in dispute had been referred to two party-nominated arbitrators who being unable to agree appointed an umpire who made an award in favour of one party. In accordance with the provisions of the arbitration agreement, the other party appealed the umpire's award to an appeal board who heard the evidence de novo and heard the opinion of the umpire in the absence of the parties. The court held this procedure to be of such a nature as to render the appeal board's award invalid on the basis of the rule that a judicial tribunal cannot hear argument on behalf of one party in the absence of the other party even where the argument comes from a non.interested party, the umpire. It is submitted that another basis for the decision could have been that in presenting his opinion to the appeal board, the umpire was acting as an advocate of the party in whose favour he had made his award. Therefore the case is an example of circumstances where a mutually-appointed arbitrator conducts himself as an advocate of one party, though the court neither observes this nor bases any conclusions on it. 
2. in arbitrator-umpire arbitration before the arbitrators have disagreed and referred the matter to an umpire,

3. in arbitrator-umpire arbitration after the dispute has been referred to the umpire, the arbitrators having disagreed.

\section{Tripartite Arbitration}

The early case authority does not seem to contemplate the possibility that the function of a party-nominated arbitrator in a tripartite arbitration could be characterized as anything other than judicial in much the same way as a mutually-nominated arbitrator's function is characterized.

An early Ontario appellate division decision ${ }^{27}$ defined the duty of impartiality incumbent upon an arbitration. Not only will actual bias disqualify; a relationship to one of the parties which "would naturally suggest ... a presumption of non-indifference" likewise disqualifies. In commenting on this case, $\mathrm{H}$. W. Arthurs states: ${ }^{28}$

The Vineberg decision has been followed in Ontario, ${ }^{29}$ and cited with approval in
Manitoba ${ }^{30}$ and in Supreme Court of Canada. ${ }^{31}$ Unfortunately, the Vineberg case
involved a two man board of arbitration rather than a tripartite board. Bias in one of
two arbitrators is as likely to produce injustice as the bias of a single judge. Bias of
one member of a tripartite board, however, is cancelled out by the bias of his
counterpart; the effective decision lies with the neutral chairman. While, surprisingly,
so astute a judge as Meredith J. failed to distinguish Vineberg on that ground in
Burford v. Chambers, he did point out that the requirement that nominated arbitrators
be neutral seems to be founded . . upon sentiment rather than reality. Feeling
himself bound by the Vineberg decision he ruefully remarked: "one's eyes cannot be
shut against the fact that in many, very many cases, the arbitrator for each party is
expected to be, and is an active advocate of the party by whom he was appointed
however much courts may insist upon impartiality and deprecate such conduct. . ."

Russell ${ }^{32}$ cites many cases $^{33}$ to support the statement that the duty to act impartially incumbent upon joint arbitrators does not differ for the single arbitrator or umpire irrespective of the fact that they have been appointed by one of the parties. Although there is no doubt that an arbitrator so appointed has an interest in favour of the party who nominated him, he must strive to act neutrally and impartially.

Although there does not appear to have been any significant change in the position since these early cases, a dictum of Devlin J. in Minister Trust v. Traps Tractors might be interpreted as contemplating a slight relaxation of the earlier strictness: ${ }^{34}$

If two parties agree to appoint an arbitrator between them, it would be, I think, implied in the contract in order to give it business efficacy . . that neither side would seek to interfere with his independence. If a party to a contract is permitted to appoint his agent to act as arbitrator in respect to certain matters under the contract, a similar term must be implied; but it is modified by the fact that the man who has to act as arbitrator in respect to some matters, and as servant or agent in respect to others, cannot remain as detached as a pure arbitrator should be.

This statement, when read together with the statement of Meredith J.

27 Vineberg v. Guardian Fire and Life Insurance Co. (1892) 19 O.A.R. 293.

2s The Three Faces of Justice-Bias in the Tripartite Tribunal, (1963) 28 Sask. Bar Rev. 147 at 152.

:a Burford v. Chambers (1894) 25 O.R. 663.

sw Turnbull v. Pipestone (1916) 29 D.L.R. 75 (Man. C.A.).

a Szilard v. Szasz [1955] S.C.R. 3.

12 The Law of Arbitration. 7th ed. 1963 at 147.

.1. Oswald v. Earl Grey (1855) 24 L.T.Q.B. 69 at 72; Watson v. Duke of Northumberland (1805) 11 Ves. 153; Maule v. Maule (1816) 4 Dow. 363; Catcraft v. Roebuck (1790) 1 Ves. Jun. 221.

" $[1954] 1$ W.L.R. 963 at 974. 
quoted in the Arthurs article, perhaps shows a willingness to recognize the practicalities of tripartite arbitration.

Section 7 of the English Arbitration Act of 1950 further indicates that the party appointed arbitrator is expected to behave judicially and impartially. It provides that where the agreement contemplates a partynominated arbitrator, if one party fails to nominate his arbitrator, the other party may appoint the arbitrator he has chosen to be the solearbitrator whose award will bind both parties, provided also that this appointment can be set aside by the court. If the legislature is willing to allow a party-nominated arbitrator to occupy the seat usually reserved for an arbitrator chosen by the parties mutually, it must not contemplate any difference in their roles-they must both be judicial officers. The English Arbitration Act of 1889 contained a similar provision. It is upon this Act that all of the Canadian provinces have modelled their arbitration statutes. ${ }^{35}$ Alberta (section 6), New Brunswick, Newfoundland, and Nova Scotia have maintained this provision while the other provinces have replaced it by permitting the party who has made its appointment to apply to the court to have it appoint an arbitrator on behalf of the defaulting party.

Another provision of the English Arbitration Act of 1950 suggests, however, that Parliament was perhaps prepared to allow a degree of partiality to exist on a tripartite tribunal. Section $9(2)$ provides that where there is a three-man board that cannot by section $9(1)$ be deemed to be an arbitrator-umpire type board, the award of any two, a majority award, shall be binding. It would have been a much greater relaxation of the impartiality rule had the section provided that the award of the chairman alone was to be binding. However, it is submitted that even the acceptance of a majority award could cause a reduction in impartiality standards since before the provision was enacted the law was that, in the absence of contrary expression in the contract, only a unanimous award would be binding. The Arbitration Act of 1889 provided that, in the absence of an expression to the contrary, the award of the arbitrators was to be final and binding. This was interpreted as meaning a unanimous award. ${ }^{36}$

The Arbitration Acts of Alberta, Newfoundland and Nova Scotia maintain the same provision as the English Act of 1889 (Alberta Arbitration Act, Schedule A). Those of Manitoba, New Brunswick, Ontario, and Prince Edward Island contain a provision that the award of the arbitrators or a majority of them shall be final and binding. In Western Clay Products Ltd. v. United Glass and Ceramic Workers of North America, ${ }^{37}$ it was held that a similar reference in the Saskatchewan Act (which has since been amended) did not mean that the majority award shall be binding in all cases. Since the provision read ". . . the award to be made by the arbitrators or by a majority of them ..., it was necessary to look to the agreement to ascertain which one was applicable. It was held that where the agreement did not provide for a majority award, the decision would be binding only if unanimous. This was followed in Longlitz v. Matador, ${ }^{38}$ a non-labour arbitration case. The result is that the provisions of Manitoba, New

is Citations for all Canadian arbitration statutes appear in Appendix A.

so Re Juransky and Gorenstein (1956) 17 W.W.R. 558 (Man. Q.B.).

s) (1965) 50 D.L.R. (2d) 84 (Sask. Q.B.).

s* (1971) 1 W.W.R. 521 (Sask. Q.B.). 
Brunswick, Ontario, and Prince Edward Island are no different in their effect than those of Alberta, Newfoundland and Nova Scotia.

Only British Columbia and Saskatchewan have followed the lead of the English Act of 1950. The British Columbia Act provides that where the reference is to three arbitrators, unless the contrary is expressed, the rule of the majority will be binding. In a 1972 amendment to its Act ${ }^{39}$ (which was likely passed in response to the Longlitz case, supra), the Saskatchewan Legislature has enacted that where there are more than two arbitrators, the award of the chairman will be binding. With this last provision, Saskatchewan has gone even further than England toward making a tripartite board susceptible to partiality in its partynominated members.

An American case has displayed a much clearer tendency away from the strict application of the same standards to both party-nominated arbitrators and mutually appointed arbitrators. In The Astoria Medical Group v. Health Insurance Plan of Greater New York, ${ }^{40}$ the New York Court of Appeal refused to disqualify an arbitrator nominated by one of the parties, although he was its founder, past president, director, and paid consultant. Interpreting the arbitration clause of the contract which provided: "One arbitrator shall be appointed by HIP and another by GROUP, who jointly shall appoint a third arbitrator", Fuld J. said: "Arising out of the repeated use of the tripartite arbitral Board, there has grown a common acceptance of the fact that the party-designated arbitrator is not and cannot be neutral, at least in the sense that a third arbitrator or a judge is. . . . In fact the very reason each of the parties' contracts for the choice of his own arbitrator is to make certain that his side will, in a sense, be represented on the tribunal. . . ."

By permitting the appointment of the director of the arbitration tribunal, the court was taking the position that the bias that can be presumed to exist in the mind of that individual would be acceptable in tripartite arbitration proceedings. Thus, since the New York Court of Appeal is willing to allow partisan arbitrators to be appointed to a tripartite board, it would seem to follow that it would be willing to allow those arbitrators to conduct themselves as advocates before the board. Although no stronger line between arbitrator and party could be imagined, the court acted with full awareness of the obvious risks inherent in its decision. It should be observed, however, that the court went on to state:

Our decision that an arbitrator may not be disqualified solely because of a relationship to his nominator or to the subject matter of the controversy does not, however, mean that he may be deaf to the testimony or blind to the evidence presented. Partisan he may be, but not dishonest.

It is submitted that the American law in relation to the role of the party-nominated arbitrator in the tripartite proceedings as represented by the Astoria case has reached a stage of development not yet approached by either Canadian or English law. Perhaps the dissenting judgment of Chief Justice Desmond is a more accurate expression of our law:41

If there is anything left of the idea that a director is an agent of his corporation

as S.S. 1972, c. 6.

(1) (1962) 182 N.E. (2d) 85 .

4 Id. at 90 . 
(Continental Securities Co. v. Belmont, 206 N.Y. 7 at 16), or anything left of the concept that an arbitrator is "a judge appointed by the parties" (Fudickar v. Guardian Mut. Life Ins. Co. 62 N.Y. 392 at 399), and that he "acts in a quasi-judicial capacity" (Matter of American Eagle Fire Ins. Co. v. New Jersey Ins. Co. 240 N.Y. 398 at 405), Dr. Baehr is as a matter of law not qualified to sit on this arbitration board. Only by so holding can we preserve a concept which is rooted not in naivete or impracticality but in integrity and principle. If Dr. Baehr can be an arbitrator when his own corporation is a party, then an individual party can name himself as his own arbitrator-judge and the whole affair becomes a cynical travesty of the arbitral process "calculated to bring the system of enforced arbitrations in disrepute" (Matter of American Eagle Fire Ins. Co. v. New Jersey Ins. Co. (Supra.)

\section{Arbitrator-Umpire Arbitration Before Disagreement}

Much of what was said earlier in relation to the position of the English and Canadian Courts regarding the role of party-nominated arbitrators in the tripartite arbitration is equally applicable here where the parties have chosen an arbitrator-umpire form of arbitration and proceedings have advanced to the stage where the parties have each nominated their arbitrator and these two people are ready to deal with the dispute. that the same strict standard of neutrality and impartiality is to be applied is evident from the judgment of Rand J. in Szilard v. Szasz:42

From its inception arbitration has been held to be of the nature of judicial determination and to entail incidents appropriate to that fact. The arbitrators are to exercise their function not as advocates of the parties nominating them and a fortiori of one party when they are agreed upon by all, but with as free, independent and impartial minds as the circumstances permit. In particular they must be untrammelled by such influences as to a fair-minded person would raise a reasonable doubt of that impersonal attitude ehich each party is entitled to.

A point upon which a distinction between the two kinds of arbitration could be based is that in some cases it may not be the intention of the parties in the arbitration-umpire situation that their arbitrators act as arbitrators at all. Rather, the parties may want them to act more as mediators or negotiators whose function is to come to a settlement acceptable to both parties through negotiations. Moreover, the understanding that if an agreement is not possible the matter is to be referred to the umpire who will decide upon the merits further strengthens the element of encouragement to settle.

If this is the function that the parties intend their arbitrators to perform, then, of course, they must each be partisan in favour of the party nominating them. It is submitted, however, that a court should be slow to construe any arbitration clause embodying such an intention, despite the apparently contrary dictum in Re Enoch and Zeretsky, Bock and $\mathrm{Co}^{43}$ This is the function normally performed by counsel before it has become necessary to submit the dispute to arbitration. As stated earlier, the holding of a judicial inquiry is a necessary element of arbitration. It may, therefore, be argued that it would be inconsistent for a court, in construing an arbitration clause, to find the intention that the arbitrators are to act as negotiators. If the only duty the parties wanted the arbitrators to perform was to appoint an umpire, it would be far more reasonable and economical for them to agree to the umpire

c2 [1955] 1 D.L.R. 370 at 371 (S.C.C.).

13 [1910] 1 K.B. 327 at 334 :

Where a case is referred to two arbitrators and an umpire it is well understood that the arbitrators act as counsel who try to settle the case without going into court; but the umpire or a single arbitrator occupies a judicial position and exercises judicial powers and is bound, as far as practicable, to follow legal rules. 
themselves rather than go to the time and expense of appointing two others to do it.

Presumably, therefore, it is within the contemplation and intention of the parties that the two arbitrators should, if possible, arrive at a just award on their own, making it unnecessary to appoint an umpire. If this is true, it must follow that the arbitrators cannot have intended to conduct themselves as advocates. Advocacy necessarily implies that there will be someone to hear the submissions, evaluate them and choose between them. If it is intended that two people should come to a just conclusion, it is inconsistent that they should be advocates. It would be absurd for two people to make opposing submissions to each other and then impartially choose which one to accept.

It may be noted, however, that the procedure followed in Wessanen's Koninklijke Fabrikien v. Isaac Modiano, Brother and Sons, Ltd. ${ }^{44}$ would not fall in line with the above reasoning. There each party appointed an arbitrator under the provisions of the arbitration clause, and the buyers and sellers respectively provided their arbitrator with documents relating to the dispute. The two arbitrators did not in fact meet but had a conversation over the telephone. They disagreed and appointed an umpire. At the hearing before the umpire, the buyers' arbitrator presented the arguments in favour of the buyers and the sellers' arbitrator put forward his conflicting arguments. The umpire's award was upheld, the court apparently approving of the procedure that was followed. The issue of whether or not this procedure could be considered an arbitration at all and the possibility that the umpire's decision might not be enforced as an award because there was no actual hearing held by the party-appointed arbitrators before they disagreed and appointed the umpire does not seem to have arisen in this case.

Although it seems impractical that the parties intended that their arbitrators function only as negotiators (since this function could be served adequately by counsel) and appointers of the umpire (since this could be done more economically by the parties themselves), there does seem to be an implication in the above case that this was indeed their intention and that the court was prepared to recognize it.

Section 8 of the English Arbitration Act, 1950 provides that unless the contrary intention is expressed, the party-nominated arbitrators will appoint the umpire immediately after they are themselves appointed. This would seem to provide encouragement for early disagreement by the arbitrators and submission to the umpire, at which point, as will be shown, the party-nominated arbitrators take on the role of advocates. None of the Arbitration Acts of the Canadian provinces contain such a provision. Rather, they provide that where there are two partynominated arbitrators, they can refer the dispute to an umpire should they be unable to agree but none provide that the umpire is to be appointed at any particular time.

While commenting on the Astoria case, Arthurs states: ${ }^{45}$

The accuracy with which the judgment reflects the expectations of the parties to both labour and commercial arbitration is clear from the privately promulgated rules governing such proceedings. The rules of the American Arbitration Association and the Code of Ethics for Labour Arbitration adopted by the National Academy of Arbitrators, both recognize the peculiar role of the nominated member of the tripartite

" [1960] 1 W.L.R. 1243 (Q.B.D.).

4. Supra, n. 28 at 154. 
board. Even in the absence of such explicit evidence in Canada, it would be highly desirable if our courts judicially noted, as Meredith J. did fifty years ago (Burford $\mathrm{v}$. Chambers) what the parties themselves expect from the process. So long as they are ad idem so that the respective appointees on the board are either both partisan or both impartial, the courts should defer to their private arrangements. To insure this consensus, some legislative rule-of-thumb would be useful.

Therefore, on the basis of logic and practicality, though it may be concluded that the role of a party-nominated arbitrator-umpire in arbitrations before disagreement does not include advocacy of the cause of his nominator, it must be recognized that his possibility exists and that, in practice, the intention is that the arbitrator is to act as negotiator on his nominator's behalf, and that this practice may well be accepted by the courts.

\section{Arbitrator-Umpire Arbitration After Disagreement}

The position of the party-nominated arbitrator is significantly different in this situation. The principle behind it is that once the arbitrators have disagreed and appointed an umpire, they have completed their judicial functions and are free to assume the role of advocates. Russell provides: 46

In some commercial arbitration, it is the practice (unless the parties give notice of their desire to attend personally or by solicitor or counsel) for the arbitrators to present the evidence to the umpire and to act as advocates; and this is not improper. . . . In such cases, the arbitrators are functus officio as arbitrators, since the umpire has taken over from them.

Russell cites French Government v. Tsurushima Maru ${ }^{47}$ in which Banks L.J. found that the practice to be:

... that unless an intimation is given to the arbitrators that they are not to act as advocates in the matter and that it is desired that either counsel or solicitor should appear ... unless such notice is given according to the practice that they (the two arbitrators) are to act and conduct the matter on behalf of the respective parties.

Relying on this practice and also on the fact, as Banks L.J. found it, that the arbitrator was instructed ". . . to act as an advocate for his client and was given the materials which would be necessary for the purpose of his acting as an advocate", the appeal to set aside the award was dismissed. The reliance on this finding of fact, it is submitted, precludes the use of this case as authority for the proposition that arbitrators automatically become advocates upon submission of the dispute to the umpire. It does show, however, that where the arbitrators are instructed to act as advocates, the following of those instructions will not result in unjust or improper conduct on their part.

In Bourgeois v. Weddell \& Company $y^{48}$ a dispute arose between buyers and sellers of a quantity of meat as to its quality. The matter was referred to arbitration. In an application to have the award set aside the issue was whether one of the arbitrators who had inspected the meat before the arbitration began was a competent witness before the umpire. In the course of his judgment, Lush J. stated:49

An arbitrator may now act in a commercial arbitration as an advocate and as an agent for the party who appoints him-when the arbitrators in a commercial arbitration have differed and the umpire has taken upon himself the burden of

\footnotetext{
ts Supra, n. 14 at 198.

47 (1921) 7 L.L. Rep. 244 (K.B.D.), aff'd 8 L.L. Rep. 403 (C.A.).

14 [1924] 1 K.B. 539.

1y $\mathrm{Id}$. at 546.
} 
adjudication, each arbitrator may be and is regarded as no longer acting judicially but as a person who is entitled either to advocate the cause of the party who appointed him or to give evidence in support of that cause.

In Wessanen's Koninklijke Fabrikien v. Isaac Modiano ${ }^{50}$ a dispute arose under a contract between buyer and seller as to the buyer's right to reject the goods. Having disagreed, the two arbitrators appointed an umpire. At the hearing before the umpire, the only persons present were the two arbitrators who argued the laws and favoured the cause of their respective parties. In the course of his judgment upholding the umpire's award, Lord Diplock stated:51

... in commercial arbitration .... where arbitrators are appointed who, upon disagreeing appoint an umpire, then, they are functus officio as arbitrators and act at the hearing before the umpire as advocates of their respective appointers . . . It is also clear that the practice, when arbitrators have been appointed in this way, is that the parties themselves are represented at the hearing before the umpire by the arbitrators and by no one else unless they express a desire to be otherwise represented.

A very strong statement of the role of the arbitrator is found in the judgment of Crutton L.J. in Naumann v. Nathan:52

So in commercial arbitrations many trades have arrived at a system that they think is much better and which probably is very much better than the system of the law courts. They each appoint an arbitrator. That arbitrator is not in the least like a judge. He acts in a way no judge would act. He hears statements from one side without requiring the presence of the other. He uses evidence submitted to him by his client, putting it forward as an advocate and not as an arbitrator. It is useless to call an arbitrator a judge. He is a negotiating advocate endeavouring to do the best he can for his client.

It is worthy of note that judicial acceptance of advocacy as part of the role of the arbitrators was at first accomplished with hesitation. This is apparent from the judgment of Lush $\mathrm{J}$. in the Bourgeois case where, while concluding that an arbitrator may now act in commercial arbitration as an advocate, he stated: 53

I have come to this conclusion with hesitation, because, speaking for myself, I think it would be very much better if the old rule as to an arbitrator's duty were still adhered to.

It may further be observed that in 1905, just fifteen years before the court accepted the procedure in the Tsurushima case, it appears to have been within the contemplation of the court that such procedure would be unacceptable. ${ }^{54}$

Furthermore, in Rahcassi Shipping v. Blue Star ${ }^{55}$ it was decided that even though the arbitrator in arbitrator-umpire arbitration becomes an advocate after the matter is referred to the umpire, his authority to act is still based on the arbitration agreement which gave rise to his appointment. He does not become the agent of his appointer. Perhaps it can be said to follow from this that he is not so much an advocate of the cause of the party who nominated him but is rather an advocate of the conclusion to which he came, impartially and judicially, during the original proceedings with the other party's arbitrator, before their disagreement, which made the appointment of the umpire necessary. The distinction is perhaps subtle but it would seem to be less of an

so Supra, n. 44.

st Ld. at 1247 .

s2 (1930) 37 Ll.L. Rep. 249 at 250.

s3 Supra, n, 48 at 546-547.

it Biglin v. Clark (1905) 49 Sul. Jo. 204.

ss [1969] 1 Q.B. 173. 
infringement of natural justice, if it is an infringement at all, for an arbitrator to advocate the acceptance of a conclusion which he arrived at by judicial means than for him to advocate a cause which he may not truly believe to be meritorious.

The English Arbitration Act of 1950 in section 9(1) provides that where the parties have agreed to submit their disputes to a tribunal which consists of three men, one chosen by each of the parties and third chosen by the first two, the third member will be considered an umpire and not a third arbitrator. This provision is not subject to contrary expression in the contract. It appears to show a definite preference for the arbitrator-umpire system. It may be noted that none of the Canadian Arbitration Acts contain such a provision.

It may be recalled here that in the examination of the role of the party-appointed arbitrator in arbitrator-umpire proceedings before reference to the umpire, the suspicion arose that the intention of the parties in some cases may be that the arbitrators are to function more as mediators and negotiators than as judicial officers. In light of this suspicion, if it is true, and what has been found to be the role of the arbitrators before the umpire, it is submitted that arbitrator-umpire arbitrations are indistinguishable from sole-arbitrator arbitrations. There is only one person whose function is to make a judicial decision in both cases. If this is the case, the provision of the English Arbitration Act discussed above can be looked upon as intending to encourage the sole-arbitrator form even when the parties have agreed to a sophisticated arrangement whereby three "arbitrators" are appointed. The Arbitration Acts of England and Canada have long shown a preference for solearbitrator arbitrations since they provide that where the form of tribunal is not specified in the agreement, reference shall be to a sole-arbitrator. ${ }^{56}$

\section{C. "Commercial" and "Legal" Arbitration-A Difference?}

It should be noted that in each of the Tsurushima, Bourgeois, Wessanen's and Naumann cases, the reference was to commercial arbitration. The obvious inference is that arbitrator advocacy is acceptable only in what is known as "commercial" arbitration. The more difficult question that arises, therefore, is what is intended to be included in the term "commercial" arbitration and what forms of arbitration are meant to be excluded therefrom?

In the Bourgeois case, Sankey J. contemplates a distinction between "legal" arbitration and "commercial" arbitration. On the opposite side is the statement by Lord Langdale M.R. in the early case of Harvey v. Shelton ${ }^{57}$ which wholly denies the existence of any difference between mercantile arbitrations and legal arbitrations. It appears from the case that the distinction between a legal arbitration and a commercial one was that the former was conducted by lawyers and the latter by merchants. If this is the basis of distinction contemplated by Sankey J. it is illogical. The justice or injustice of arbitration advocacy cannot vary with the profession of the arbitrator.

Another possible means of distinguishing between the two may be the type of issue that the arbitration is intended to resolve. In three of the cases mentioned above the dispute concerned the quality of the

\footnotetext{
96. See Werry and Carew. An Inquiry into the Preponderance of Tripartite Arbitration Boards in Ontario. Queen's Law Journal, [1971] Vol. 1, no. 1 at 67 for a discussion of the reasons for the use of tripartite boards rather than sole arbitrators.

s: (1884) 7 Beav. 455.
} 
subject matter of the contract. It is apparently recognized that quality arbitrations can, without injustice, follow a procedure radically different from more formal arbitrations. ${ }^{58}$ In particular, it may not be necessary for a hearing to be held, the umpire determining for himself the quality of the subject matter. Perhaps, then, the term "commercial" arbitration is meant to refer to arbitrations where the only question is one of fact in a commercial transaction. However, the term used in the Wessanen's case cannot be made to fit the definition because there the question before the arbitrators was one of law: the right of rejection of goods for an admitted breach of condition by the seller.

In three of the above-mentioned cases, the procedure used for arbitration appears to be that adopted by the particular trade or market. Perhaps "commercial" arbitration is meant to refer to arbitrations within a particular trade or commercial market where unique procedures have been established. It should be noted, however, that in the Bourgeois case the advocacy procedure was accepted though not proven to be an established trade procedure.

Introduction to a Business Man's Guide to Commercial Arbitration ${ }^{59}$ states that the disputes in the business world seldom involve great legal issues. On the contrary, they concern the same evaluation of facts and interpretation of contract terms that businessmen and their lawyers are accustomed to dealing with everyday. Consequently, when differences arise out of day-to-day commercial affairs, parties often prefer to settle them privately and informally in a business-like way. That is what commercial arbitration is for.

Martin Domke in his book Commercial Arbitration provides: ${ }^{60}$

Commercial arbitration has been developed in the United States as a way of life in the business community-a self-regulating method for the solution of disputes where contracting parties maintain control of the procedure. Such proceedings have been in some segments of trade and commerce as almost the only means of settlement. Flexibility of the arbitration process guarantees that any determination of commercial disputes by the arbitrator will be impartial and fair. Because arbitration is voluntary, it has to prove its value and effectiveness in order to become acceptable.

In the absence of a definition for the term "commercial arbitration", it seems difficult to determine the basis of the distinction between it and "legal arbitration". The term is probably most commonly used to describe that category of arbitration proceedings undertaken to resolve disputes among businessmen as distinguished from the larger category of labour arbitration. In labour arbitration, it appears to be well accepted that party-nominated arbitrators are intended to be partisan and to act as advocates at all times during the arbitration." If it is "labour arbitration" that is intended to be excluded by the use of term "commercial arbitration" in these cases, the latter term cannot have been intended to describe a class of arbitration to which arbitrator advocacy before an umpire is restricted.

If any restrictive application was once intended by the use of the term "commercial" it seems to have been abandoned in the most recent cases. In Rahcassi Shipping v. Blue Star, Roskill J. first refers to the

\footnotetext{
5o Russell, supra, n. 28 at 179.

s9 American Arbitration Association, New York, 1964 at 2.

so Callagham, Mundelien, III. (1970).

o1 Re Arbitration Act, Re Gainers and Local 319 United Packinghouse Workers of America (1964) 47 W.W.R. 544 (Alta. S.C.).
} 
Wessanen's case and then describes the normal arbitration procedure:62

Each party to the contract contemplates that his arbitrator, if he disagrees with the other arbitrator, will join with the other arbitrator in appointing an umpire, that each arbitrator will then appear before the umpire duly appointed under the clause and argue the case before the umpire as advocate.

There does not appear to be intended a description of the practice in a restricted area known as "commercial arbitration".

\section{Summary}

It may be helpful at this point to summarize what has been so far said as to the role of the arbitrator.

First, as to an arbitrator appointed mutually by the parties, it was found that his role could be characterized as judicial and that the main consequence of this was that he had a duty to adhere to the rules of natural justice. From this it follows naturally that he cannot conduct himself as an advocate of either party's cause.

Second, as to arbitrator's appointed by each party individually, it was found that the judicial characterization still applied. In tripartitearbitration this was in the face of an apparent trend in the U.S.A. away from the strict requirement of impartiality for the party-nominated arbitrators.

In arbitrator-umpire arbitration it was found that before the arbitrators disagreed and submitted the dispute to umpire, they could not conduct themselves as advocates. The suspicion was raised, however, that the parties might have intended in some cases that the arbitrators function more as mediators or negotiators in which case they would not be judicial officers. It was found that after there had been reference to the umpire, the courts initially had a strict view of the role of the arbitrator and would have invalidated an award on the ground that the arbitrator took on the role of an advocate before the umpire. Nevertheless the practice of such advocacy developed within particular trades and the court accepted it where it was proved to be the "usual way". The practice became so widespread that its acceptance by the courts in all arbitrator-umpire arbitration followed. Thus, the partynominated arbitrators are generally considered to be advocates of their nominator's cause before the umpire. If the suspicion as to the role before reference to the umpire is correct, the arbitrator-umpire form of arbitration becomes indistinguishable from that of the sole-arbitrator.

\section{THE ROLE OF THE ARBITRATOR AS SEEN BY THE PRACTITIONER}

In order to evaluate the role of an arbitrator as seen by the practitioner, four interviews were conducted with two lawyers, one engineer and one lawyer-engineer. It was made clear during the course of each interview that the arbitrator-umpire form of tribunal is rarely, if ever, used in Alberta. The following are the conclusions and summary of the results of those four interviews.

The first interview revealed that the role of the party-nominated arbitrator was that of a judge completely impartial and judicial. The only possible advantage in having a three man tribunal over a one man tribunal was that a better "mix" of expertise could be achieved. Not only 
does a compromise often result but the parties expect it. Unless the contrary was expressed in the contract, the strict rules of evidence should not apply.

The second interview also expressed the conviction that the arbitrators should conduct themselves impartially and judicially. Each arbitrator should have faith in the impartiality of the other and of the chairman. However, it was observed that it was humanly impossible to rid oneself of bias which had developed over the years. Built in prejudices are developed due to the previous close association with the nominator and this probably affects the judgment and which undoubtedly is a major reason for nomination or appointment. It was also suggested that procedural guidelines would be very valuable to the arbitrators and the parties to an arbitration. In the absence of an equivalent to the American Arbitration Association which has had success with a system whereby the association appoints the three arbitrators from a list of men who are professional arbitrators and are therefore undoubtedly independent, a reasonable alternative to the three man tribunal would be one man arbitration where the sole arbitrator would have the power to call his own expert witnesses (to provide the expertise lost by the reduction from a three man tribunal to a one man tribunal). These experts would function as Amicus Curiae and could be questioned by both parties to the dispute.

The observation of the third interviewee who has had a great deal of experience in arbitration was that the party-nominated arbitrators are always partial in favour of the nominator. It was further revealed that there was a distinction between arbitration where the parties were represented by counsel and those where they were not. In the latter case the arbitrators are not only partial but are the advocates of the nominator's cause. In the discussion which follows the hearing, the arbitrators invariably put forth the nominator's case and take extreme positions realizing that in the bargaining process they will be forced to come down. Interestingly enough this interview revealed that the tribunal usually comes to a unanimous conclusion. It was suggested that the best role for the party-nominated arbitrator to play is that of an advocate.

It was suggested in the fourth interview that the arbitrator should be impartial and come to a decision judicially though it was not inconsistent with this for them to present the case of their nominator and to stress its strong points.

One of the observations made by all of the gentlemen who were interviewed is worthy of note. Arbitration clauses are currently common in contracts, especially in the construction industry. The frequency of arbitration, however, is not that great and the reason for this was suggested to be because parties who include arbitration clauses do so because they want to settle their disputes amicably. They therefore have a high propensity to find a solution through negotiations before reference to arbitration is necessary. 


\section{APPENDIX A}

\section{ARBITRATION STATUTES}

\section{Canadian}

Alberta

British Columbia

-Arbitration Act, R.S.A. 1970, c. 21.

Manitoba

-Arbitration Act, R.S.B.C. 1960, c. 14.

New Brunswick

-Arbitration Act, R.S.M. 1970, c. A-130.

Newfoundland

-Arbitration Act, R.S.N.B. 1952, c. 9.

Nova Scotia

Ontario

-Judicature Act, R.S.N. 1952, c. 114, ss. 194-214.

-Arbitration Act, R.S.N.S. 1967, c. 12.

-Arbitration Act, R.S.O. 1970, c. 25.

Prince Edward Island -Arbitration Act, R.S.P.E.I. 1951, c. 12.

Saskatchewan

-Arbitration Act, R.S.S.S. 1965, c. 106 amended S.S. 1972 , c. 6.

England

Arbitration Act, 52 \& 53 Victoria, 1889, c. 49, repealed by Arbitration Act, $15 \& 16$ Geo. VI, 1950 , c. 27.

United States

New York-Civil Practice Laws and Rules Act 75 (McKinney 1963).

\section{APPENDIX B}

The Arbitration Act, R.S.A. 1970, c. 21 , s. 5

During the course of research for this paper, a question was raised concerning section 5 of The Arbitration Act, R.S.A. 1970, c. 21. Section 5 provides:

5. (1) A party to a submission may serve on the other party or parties or on the arbitrators, as the case may be, a notice in writing requiring him or them to appoint an arbitrator, umpire or third arbitrator,

(a) when a submission provides that a reference shall be to a single arbitrator and after differences have arisen all the parties to the difference do not concur in the selection of such arbitrator, or

(b) when an appointed arbitrator refuses to act or is incapable of acting or dies and the submission does not show that it was intended that the vacancy should not be filled and the parties do not fill the vacancy, or

(c) when the parties or two arbitrators are at liberty to appoint an umpire or third arbitrator and do not appoint him, or

(d) when an appointed umpire or arbitrator refuses to act or is incapable of acting or dies and the submission does not show that it was intended that the vacancy should not be filled and the parties or arbitrators do not fill the vacancy.

(2) If the appointment is not made within seven clear days after the service of the notice, the Court or a judge may on application by the party who gave the notice appoint an arbitrator, umpire or third arbitrator, as the case may be, who has the same powers to act in the reference and make an award as if he had been appointed by consent of all parties. 
The point raised concerns the application of the section to the situation where two parties have entered into a contract containing an arbitration clause providing that where a dispute arises, each party shall at once appoint an arbitrator and these shall jointly select a third. The problem arises where one party appoints its arbitrator but the other party refuses to. The question that arises is whether, under these circumstances, section 5 is operative to provide the court with the power to appoint an arbitrator for the defaulting party.

Subsection 5(1) uses the language "to appoint an arbitrator, umpire or third arbitrator" as does subsection 5(2). There appears to be an anomaly, however, in paragraph $5(1)(\mathrm{c})$, which covers the situation posed above, in that the language used therein is "to appoint an umpire or third arbitrator" and no reference is made to the appointment of "an arbitrator". Only if subsection $5(1)$ is read as generally allowing one party to serve notice on the other to appoint, and such power is not restricted to one of the four instances in paragraphs (a) to (d), can it be said that the court, under subsection $5(2)$, would have the power to appoint an arbitrator for the defaulting party in the situation posed above.

The present section 5 was cast in its present form in the Revised Statutes of Alberta, 1955, c. 15. The forerunner to this section was passed originally as section 6 of The Arbitration Act, S.A. 1909, c. 6, which provided:

6. In any of the following cases-

(a) Where a submission provides that a reference shall be to a single arbitrator and all the parties do not after differences concur in the appointment of an arbitrator;

(b) If an arbitrator refuses to act or is incapable of acting or dies and the submission does not show that it was intended that the vacancy should not be supplied and the parties do not supply the vacancy;

(c) Where the parties or two arbitrators are at liberty to appoint an umpire or third arbitrator and do not appoint him;

(d) Where an appointed umpire or arbitrator refuses to act or is incapable of acting or dies and the submission does not show that it was intended that the vacancy should not be supplied and the parties or arbitrators do not supply the vacancy;

any party may serve the other parties or the arbitrators as the case may be with a written notice to appoint an arbitrator, umpire or third arbitrator. If the appointment is not made within seven clear days after the service of the notice the court or a judge may on application by the party who gave the notice appoint an arbitrator, umpire or third arbitrator who shall have the like powers to act in the reference and make an award as if he had been appointed by consent of all parties.

It is clear that a reading of paragraph $6(\mathrm{c})$ maintains the same possibility of denying the court the power to appoint an arbitrator for the defaulting party.

In Ontario, section 8 of The Arbitration Act, R.S.O. 1970, c. 25, provides: 
8. (1) In any of the following cases,

(a) where a submission provides that the reference is to a single arbitrator and the persons whose concurrence is necessary do not, after differences have arisen, concur in the appointment of an arbitrator; or

(b) where an arbitrator, an umpire or a third arbitrator is to be appointed by a person and such person does not make the appointment; or

(c) unless the submission otherwise provides, where an arbitrator, an umpire or a third arbitrator refuses to act or is incapable of acting or dies and the vacancy is not supplied by the person having the right to fill the vacancy,

a party may serve the other party or the arbitrators, or the person who has the right to make the appointment, as the case may be, with a written notice to concur in the appointment of a single arbitrator or to appoint an arbitrator, umpire or third arbitrator.

(2) If the appointment is not made within seven clear days after the service of the notice, a judge may, on application by the party who gave the notice, appoint an arbitrator, umpire or third arbitrator, who shall have the like powers to act in the reference and make an award as if he had been appointed by consent of all parties.

It is clear that paragraph $8(1)(b)$ would entitle the court to appoint an arbitrator for the defaulting party. 